\title{
Adsorption of Extracellular Polymeric Substances Derived from S. cerevisiae to Ceria Nanoparticles and the Effects on Their Colloidal Stability
}

\author{
Shota Masaki ${ }^{1,+}{ }^{+}$, Yuriko Nakano ${ }^{1,+}$, Kenta Ichiyoshi ${ }^{1}$, Keisuke Kawamoto ${ }^{1}$, Ayaka Takeda ${ }^{1}$, \\ Toshihiko Ohnuki ${ }^{2}$, Michael F. Hochella Jr. and Satoshi Utsunomiya ${ }^{1, *}$ \\ 1 Department of Chemistry, Kyushu University, 744 Motooka, Nishi-ku, Fukuoka-shi 819-0395, Japan; \\ masaki.db6.shohta@jp.nssmc.com (S.M.); y.nakano@chem.kyushu-univ.jp (Y.N.); \\ kentucky@chem.kyushu-univ.jp (K.I.); k1210.kuu@gmail.com (K.K.); takedaayaka185@gmail.com (A.T.) \\ 2 Laboratory for Advanced Nuclear Energy, Institute of Innovative Research, Tokyo Institute of Tecnology, \\ 2-12-1 Ookayama, Meguro-ku, Tokyo 152-8550, Japan; toshi.ohnuki@lane.iir.titech.ac.jp \\ 3 Department of Geosciences, Virginia Tech, Blacksburg, VA 24061, USA; hochella@vt.edu \\ 4 Geosciences Group, Energy and Environment Directorate, Pacific Northwest National Laboratory, Richland, \\ WA 99352, USA \\ * Correspondence: utsunomiya.satoshi.998@m.kyushu-u.ac.jp; Tel.: +81-92-802-4168 \\ + These two authors contributed equally to this work.
}

Received: 23 May 2017; Accepted: 7 July 2017; Published: 11 July 2017

\begin{abstract}
In order to understand the adsorption preferences of extracellular polymeric substances (EPS) components derived from fungus Saccharomyces cerevisiae on sparingly soluble $\mathrm{CeO}_{2}$ nanoparticles (CeNPs), the adsorption experiments of the EPS including organic matter with low molecular weight have been performed at $\mathrm{pH} 6.0$ at room temperature $\left(25 \pm 1^{\circ} \mathrm{C}\right)$. The subsequent effects of the coating on the dispersibility of CeNPs was systematically measured as a function of time and ionic strength ranging from 1 to $1000 \mathrm{mmol} \mathrm{L}^{-1}$. Among the EPS and other components, orthophosphate and saccharides preferentially adsorb onto CeNPs, and proteins are the only major $\mathrm{N}$-compounds adsorbing onto the CeNP surfaces. Adsorption of orthophosphate resulted in a dramatic decrease in $\zeta$ potential to $-40 \mathrm{mV}$ at $\mathrm{pH}>5$, whereas the EPS adsorption suppressed the deviation of $\zeta$ potential within a narrow range $(-20-+20 \mathrm{mV})$ at $\mathrm{pHs}$ ranging from 3 to 11 . Critical aggregation concentrations (CAC) of an electrolyte $(\mathrm{NaCl})$, inorganic orthophosphate, and EPS solutions are $0.01,0.14$, and $0.25 \mathrm{~mol} \mathrm{~L}^{-1}$, respectively, indicating that the EPS adsorption suppresses aggregation of CeNPs by the electrostatic repulsive forces derived from the adsorbed orthophosphate and the steric barrier formed by organic matter on the nanoparticle surfaces. Therefore, the EPS derived from fungus $S$. cerevisiae can potentially enhance colloidal dispersibility of CeNPs at circumneutral $\mathrm{pH}$.
\end{abstract}

Keywords: EPS; ceria; adsorption; aggregation

\section{Introduction}

Natural, engineered, and incidental nanoparticles are ubiquitous in all portions of the Earth system [1-3]. In groundwater, naturally occurring nanoparticles include inorganic, organic substances, and mixed substances $[4,5]$. They can also play a key role in the migration of radionuclides $[4,6-8]$. Groundwater colloid transport, even at the nano-scale, is generally governed by the hydrology and geochemistry of the subsurface, although very different principals often apply in the nano-scale relative to larger colloids. The mobility of nano-scale colloids in subsurface environments are often delicately dependent on their physico-chemical properties such as their size and shape, including surface topography, as well as surface charge, attached ligands, and aggregation state. In such processes, 
aggregation of nanoparticles as associated substances is the most important process that constrains the colloid size. It is well known that the aggregation of nanoparticles in simple aqueous systems is a function of ionic strength and $\mathrm{pH}$ of the solution [9-11]. In complex, natural systems, colloidal behavior is greatly affected by the interaction with natural organic matter such as humic and fulvic acids, and a vast assortments of other organic compounds [12-15], among many other substances in natural waters, from dissolved ions and small inorganic complexes, to other inorganic nanomaterials.

In addition to naturally occurring nanoparticles, microorganisms play an important role in the elemental cycles in the Critical Zone of the Earth. For example, biofilms, cell lysis, and exudates are important sources of organic compounds in underground environments [16]. In particular, high molecular weight compounds derived from cell cultures are known as extracellular polymeric substances (EPS), which mainly consist of polysaccharides, amino sugars, proteins, teichoic acid, and nucleic acids [17]. A recent study reported that bacterial EPS play a critical role in biosorption, biomineralisation, redox cycling, trapping and deposition of nanoparticles, mineral dissolution, and metal solution complexation [18]. Due to ubiquitous and abundant occurrence of nanoparticles and microorganisms in the surface and subsurface environments, they can readily encounter and interact with one another in aqueous systems as revealed in a previous study of nanoparticles adsorbing onto microbial surfaces [19]. In addition, it is well known that microorganisms can stimulate the production of nanoparticles in a great variety of remarkable ways [20-23].

The effects of EPS on the colloidal stability of engineered nanoparticles have been recently studied. EPS derived from plankton enhanced the dispersion of $\mathrm{Cu}$-based nanoparticles [24] and $\mathrm{TiO}_{2}$ nanoparticles $[25,26]$ by chemically sorbing to their surfaces. It was also reported that EPS derived from periphyton stabilizes ceria nanoparticles [27]. In addition, a previous study reported preferential adsorption of phosphorylated macromolecules in bacterial EPS to micron-sized particle of goethite [28].

Although a suite of experimental data have been collected on EPS adsorption to nanoparticles, along with the effects of the EPS coating on the colloidal stability of these nanoparticles, there are limited studies that systematically and quantitatively analyze the preferential adsorption of EPS components and details of the subsequent effects on their colloidal stability. The aim of this study was to quantitatively investigate the preferential adsorption of EPS components derived from fungus S. cerevisiae onto sparingly soluble $\mathrm{CeO}_{2}$ nanoparticles (CeNPs), which was used as a surrogate for actinide oxide nanoparticles such as uranium and plutonium dioxide, and also as one of the representative engineered nanomaterials presently being produced. Subsequently the present study aims to evaluate the role of the preferentially-adsorbed EPS components on the surface property and aggregation behavior of the CeNPs at circumneutral pHs. In addition, the previous studies investigated the effects of only polymeric substances in the exudate of microorganisms, excluding the effects of molecules with low molecular weight. Unlike those previous studies, the present study elucidates the total effects including the small molecules and inorganic cations in addition to polymeric substances.

\section{Materials and Methods}

\subsection{Characterization of $\mathrm{CeO}_{2}$ Nanoparticles (CeNPs)}

Synthetic CeNPs were purchased from Strem Chemicals, Inc., Newburyport, MA, USA, (\#58-1400, $\sim 7 \mathrm{~nm}$ ). Detailed description of these CeNPs can be found in our previous work [29]. Briefly, the CeNPs are approximately spherical in shape with an average diameter of $\sim 7 \mathrm{~nm}$. The surface area was measured to be $70.2 \mathrm{~m}^{2} \mathrm{~g}^{-1}$ using a BET single point analysis. The measured surface area is smaller than anticipated for fully disperse spherical nanoparticles of $<10 \mathrm{~nm}$, indicating the CeNPs are aggregated to some extent prior to use in experiments.

\subsection{Characterization of the Extracellular Polymeric Substances (EPS)}

Saccharomyces cerevisiae X-2180 was grown in $150 \mathrm{~mL}$ of sterilized YPD medium containing $10 \mathrm{~g} \mathrm{~L}^{-1}$ yeast extract, $20 \mathrm{~g} \mathrm{~L}^{-1}$ peptone, and $20 \mathrm{~g} \mathrm{~L}^{-1}$ dextrose. The yeast was incubated for $18 \mathrm{~h}$ on a rotary 
shaker at 120 revolutions per minute (rpm) at $25 \pm 1{ }^{\circ} \mathrm{C}$. The cells were separated from the suspension by centrifugation for $10 \mathrm{~min}$ at $5000 \mathrm{rpm}$ and washed three times with $1 \mathrm{mmol} \mathrm{L}{ }^{-1} \mathrm{NaCl}$ solution. The yeast was transferred to $50 \mathrm{~mL}$ of $1 \mathrm{mmol} \mathrm{L}^{-1} \mathrm{NaCl}$ in a polypropylene tube. The cell density in all exposure solutions was adjusted to 2.0 dry $\mathrm{g} \mathrm{L}^{-1}$. The $\mathrm{pH}$ of the exposure solutions was adjusted to $3.0 \pm 0.1$ by adding $1.0 \mathrm{~mol} \mathrm{~L}{ }^{-1} \mathrm{HNO}_{3}$ solution at the appropriate proportions. The $\mathrm{pH}$ was measured using a tpx-999i pH meter (PCE108CW-SR) equipped with a PCE108CW-SR electrode. After $72 \mathrm{~h}$, the suspension was filtered through a $0.20 \mu \mathrm{m}$ polytetrafluoroethylene (PTFE) membrane filter (J020A047A, ADVANTEC MFS, Inc., Dublin, CA, USA) to remove the cells. The filtrate was labeled as the EPS solution. The EPS contains organic and inorganic phosphorous; the total P concentration was determined using an inductively coupled plasma mass spectrometry system (ICP-MS; Agilent 7500c, Agilent, Santa Clara, CA, USA) and the concentration of inorganic orthophosphate was analyzed using an ion chromatography analyzer (761 Compact IC, Metrohm, Herisau, Switzerland). The detection limit of P in the ICP-MS analysis is 0.5 ppb. Phosphorus standard solution (Wako, P: $1000 \mathrm{~g} / \mathrm{L}$ ) was used for calibration. The concentration of dissolved organic carbon (DOC) was measured using a total organic carbon analyzer (TOC; TOC-VE, Shimadzu, Kyoto, Japan). The detection limit of the TOC analyzer is $50 \mu \mathrm{g} / \mathrm{L}$ and the reproducibility of the data is within $2 \%$. Identification of the functional group in the EPS was completed by the following procedure; the $\mathrm{pH}$ of the EPS solutions was adjusted to $6.0 \pm 0.1$ from $4.8 \pm 0.3$ by adding $1.0 \mathrm{~mol} \mathrm{~L}^{-1} \mathrm{NaOH}$ solution at the appropriate proportions. The EPS solutions were subsequently evaporated to dryness at $65{ }^{\circ} \mathrm{C}$, and the precipitate was quickly dehydrated at $70^{\circ} \mathrm{C}$ in a thermostatic oven overnight to avoid degradation by enzyme. Although this heating treatment can lead to denaturation of polymeric substances, it does not significantly affect the results in the present study, because we do not discuss the structure of polymers but the relative abundance between a few different species of $\mathrm{N}, \mathrm{C}, \mathrm{O}$, and P. The dried EPS was analyzed using an attenuated total reflectance Fourier transform infrared (ATR-FTIR; JASCO, FT/IR-620) equipped with a deuterated L-alanine Triglycine Sulphate (DLATGS) detector, a single bounce attenuated total reflectance attachment, and a ZnSe crystal. Thirty-two scans were performed in total with a spectral resolution of $4 \mathrm{~cm}^{-1}$, and averaged.

\subsection{Adsorption of EPS onto $\mathrm{CeO}_{2}$ Nanoparticles (CeNPs)}

Stock suspension containing $5000 \mathrm{mg} \mathrm{L}^{-1}$ CeNPs was prepared and ultrasonicated (Fine, FU-3H) for $10 \mathrm{~min}$. For comparison, three kinds of solutions were prepared; (i) $1 \mathrm{mM} \mathrm{NaCl}$ solution (Control); (ii) $1 \mathrm{mM} \mathrm{NaCl}+0.16 \mathrm{mM} \mathrm{H}_{3} \mathrm{PO}_{4}$ solution (inorganic $\mathrm{H}_{3} \mathrm{PO}_{4}$ ), of which the $\mathrm{P}$ concentration is the same as that in the EPS solution; and (iii) EPS solution that contains $1 \mathrm{mM} \mathrm{NaCl}$ solution due to the condition during the extraction procedure. The $\mathrm{pH}$ of these suspensions was adjusted to $6.0 \pm 0.1$ by mixing $1.0 \mathrm{~mol} \mathrm{~L}{ }^{-1} \mathrm{NaOH}$ solution at the appropriate proportion. $30 \mathrm{~mL}$ portions of these solutions were added to an aliquot of CeNPs stock solution in such a way that the concentration of CeNPs was adjusted to 10 or $100 \mathrm{mg} \mathrm{L}^{-1}$. The CeNPs concentrations were chosen for measurements using multi analytical techniques. The $3.0 \mathrm{~mL}$ of the supernatants was sampled at $0,0.16,0.5,1,3,6$, 13, 18, and $24 \mathrm{~h}$. The suspension was filtered through a $10 \mathrm{kDa}$ ultrafiltration unit (Amicon Ultra, Millipore Ltd., Carrigtwohill, Ireland). Prior to separation, the filter unit was thoroughly washed with $0.1 \mathrm{~mol} \mathrm{~L}^{-1} \mathrm{NaOH}$ solution and Milli-Q water to remove trace glycerin from the ultrafiltration unit. The ultrafiltration was completed using an Eppendorf ultracentrifuge system at 13,400 rpm (maximum rotation speed) that generates 12,100 G, and the filtrate was used for the subsequent solution analyses. To determine the amount of organic matter and phosphorous that adsorbed on CeNPs, the concentrations of DOC and total P in the filtrate were measured by the same analytical methods described in the previous section. For the ATR-FTIR and X-ray photoelectron spectroscopy (XPS) analyses on the adsorbed EPS, either $200 \mathrm{~mL}$ or $2000 \mathrm{~mL}$ of three different solutions was added to aliquots of CeNPs stock solutions in such a way that the concentration of CeNPs was 10 or $100 \mathrm{mg} \mathrm{L}^{-1}$ at $\mathrm{pH}$ 6.0. These suspensions were batch (statically) reacted for $24 \mathrm{~h}$, and collected by using a $0.025 \mu \mathrm{m}$ nitrocellulose membrane filter (VSWP04700, ADVANTEC MFS, Inc., Dublin, CA, USA). Then, the 
residue was rinsed thoroughly with ultra-pure water, and dehydrated at $70{ }^{\circ} \mathrm{C}$ in a thermostatic oven overnight. The ATR-FTIR measurement of EPS adsorbed on CeNPs was completed using the same procedure as described in the previous section. The XPS analysis of both EPS and EPS adsorbed onto CeNPs was performed on a ESCA 5800 (ULVAC-PHI Inc., Chigasaki, Japan) system. The binding energies of each spectrum were calibrated by shifting the main $\mathrm{O}$ 1s peak to $529.0 \mathrm{eV}$. The zeta $(\zeta)$ potential was measured for the CeNPs suspensions (100 ppm or $10 \mathrm{ppm}$ ) in $1 \mathrm{mM} \mathrm{NaCl}$ solution using a Zeta Sizer Nano ZS (Malvern Instruments Inc., Worcestershire, UK). The pH was first adjusted to 6.0 and adjusted to the targeted value by using $\mathrm{NaOH}$ or $\mathrm{HNO}_{3}$.

\subsection{Aggregation and Sedimentation}

Prior to the aggregation and sedimentation experiments, the stock suspension was sonicated for $10 \mathrm{~min}$. Three solutions, (i) (iii) were added to aliquots of CeNPs stock solution to adjust the concentration of CeNPs to $100 \mathrm{mg} \mathrm{L}^{-1}$. The colloidal size was intermittently measured during the aggregation process using dynamic light scattering (DLS; ELSZ-2PS, Otsuka Electronics Co. Ltd., Osaka, Japan). The dynamic aggregation process was monitored using a UV-vis spectrophotometer (V-530; JASCO, Tokyo, Japan), measuring the back scattering intensity of the CeNPs at $340 \mathrm{~nm}$ in the solutions as a function of time. The absorbance was measured every $5 \mathrm{~s}$ for $10 \mathrm{~min}$. The longer period was not considered in this study to eliminate the effects of deposition processes so that the results can be simply interpreted as aggregation process based on the Mie theory (see Appendix A). The scattering intensity depends on the concentration of particles in the solvent and the particle size. In the present experiment, the effect of particle size on the absorbance is negligibly small according to the Mie theory as discussed in the Appendix A. Thus, the absorbance changes depend only on the particle concentration. In general, the time-dependent decrease in the concentration of particles (particles per $\mathrm{cm}^{3}$ ) in a mono-dispersed suspension due to collisions by Brownian motion can be represented by a second-order rate law:

$$
\frac{1}{N(t)}-\frac{1}{N_{0}}=K_{\mathrm{p}} t
$$

where $K_{\mathrm{p}}$ is the rate constant $\left(\mathrm{cm}^{3} \mathrm{~s}^{-1}\right) . N(t)$ is the number of particles (particles $\left.\mathrm{cm}^{-3}\right)$ at the reaction time, $t$. $N_{0}$ is the initial number of particles. Because, in the present experiment, the absorbance is directly correlated with only the concentration of CeNPs, the term $N$ in Equation (1) can be replaced by the absorbance, $A$, with the modified coefficient $K_{\mathrm{p}}{ }^{\prime}$ as follows:

$$
\frac{1}{A(t)}-\frac{1}{A_{0}}=K_{\mathrm{p}}{ }^{\prime} t
$$

The critical aggregation concentration (CAC) was determined for the conditions (i) (iii) based on the $K_{\mathrm{p}}{ }^{\prime}$ plot as a function of the electrolyte $(\mathrm{NaCl})$ concentration ranging from 1 to $1000 \mathrm{mmol} \mathrm{L}^{-1}$ to compare the effects of EPS with that of other substances. In the diagram, the electrolyte concentration showing the maximum reduction in absorbance was assigned to be the CAC.

\section{Results and Discussion}

\subsection{Characterization of EPS}

Table 1 summarizes the composition of the EPS in $1.0 \mathrm{mmol} \mathrm{L}^{-1} \mathrm{NaCl}$ after $72 \mathrm{~h}$ of incubation for yeast to release EPS, showing that the EPS is mainly composed of $\sim 70 \mathrm{mg} \mathrm{L}^{-1}$ organic carbon, $\sim 0.50 \mathrm{mmol} \mathrm{L}^{-1} \mathrm{~K}^{+}$, and $\sim 0.16 \mathrm{mmol} \mathrm{L}^{-1}$ total phosphorous including $\sim 0.12 \mathrm{mmol} \mathrm{L}^{-1}$ orthophosphate. The $\mathrm{Na}^{+}$concentration does not represent sodium release from the yeast, but the sodium initially added to the solution to adjust the ionic strength. The fraction of orthophosphate is approximately $80 \%$ in the total $\mathrm{P}$ concentration and the rest is $\mathrm{P}$ associated with organic compounds. Masaki and others have already reported that the dissolved organic matter in the EPS consists of various species as determined by HPLC [29]. 
Table 1. Major composition of EPS (extracellular polymeric substances) solution extracted from S. cerevisiae in $1.0 \mathrm{mmol} \mathrm{L}^{-1} \mathrm{NaCl}$ for $72 \mathrm{~h}$ of incubation. The mass of EPS was determined to be $306 \pm 83 \mathrm{mg}$ per liter.

\begin{tabular}{cc}
\hline Compound & Concentration \\
\hline Dissolved organic carbon & $72 \pm 20 \mathrm{mg} \mathrm{L}^{-1}$ \\
Dissolved nitrogen & $42 \pm 11 \mathrm{mg} \mathrm{L}^{-1}$ \\
Total phosphate & $0.16 \pm 0.07 \mathrm{mmol} \mathrm{L}^{-1}$ \\
Orthophosphate & $0.12 \pm 0.02 \mathrm{mmol} \mathrm{L}^{-1}$ \\
$\mathrm{~K}^{+}$ & $0.49 \pm 0.03 \mathrm{mmol} \mathrm{L}^{-1}$ \\
\hline
\end{tabular}

Figure 1 shows the ATR-FTIR spectra of EPS prior to contact with CeNPs. The band assignments are summarized in Table 2, along with supporting references. A large absorption band at $1374 \mathrm{~cm}^{-1}$ corresponds to symmetric stretching of COO- groups $\left(v_{\mathrm{s}} \mathrm{C}-\mathrm{O}\right)$ that are derived from proteins and carboxylated polysaccharides [30]. The band at $\sim 1600 \mathrm{~cm}^{-1}$ corresponds to the stretching vibration of $\mathrm{C}=\mathrm{O}$ groups in amide I (amides associated with proteins). The band at $\sim 1514 \mathrm{~cm}^{-1}$ corresponds to the stretching vibration of $\mathrm{C}-\mathrm{N}$ groups and deformation vibrations of $\mathrm{N}-\mathrm{H}$ groups in amide II (-CO-NHof proteins) [31]. These bands at 1600 and $1514 \mathrm{~cm}^{-1}$ indicate the presence of proteins in the EPS. The band at $\sim 1110 \mathrm{~cm}^{-1}$ corresponds to ring vibrations of $\mathrm{C}-\mathrm{O}-\mathrm{C}$ in polysaccharides and stretching vibrations of $\mathrm{P}=\mathrm{O}$ bonds in proton dissociated orthophosphate. In addition, the band at $\sim 1044 \mathrm{~cm}^{-1}$ corresponds to symmetric stretching vibrations of $\mathrm{P}=\mathrm{O}$ in the phosphoryl group. It should be noted that the phosphate bands overlap the band of polysaccharide vibrations and these features are difficult to separate; nevertheless, it is concluded that polysaccharides and phosphoryl species can be identified as the EPS constituents released from S. cerevisiae. These species are also contained in the EPS released from other microorganisms [32-34].

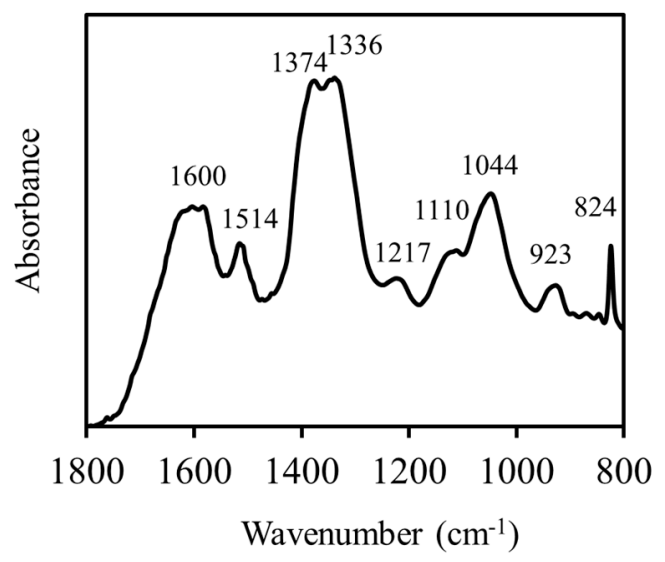

Figure 1. ATR-FTIR spectra of pristine EPS at $\mathrm{pH}$ 6.0.

Figure 2 shows the XPS spectra of the EPS prior to the adsorption to CeNPs. Based on a peak assignment proposed by Badireddy and others [37], the $C$ 1s peak (Figure 2A) was resolved into four component peaks, which were assigned as follows: (i) the peak at $284.8 \mathrm{eV}$ is attributed to $\mathrm{C}-(\mathrm{C}, \mathrm{H})$ in lipids, amino acid side chains, or saccharide ring chains; (ii) the peak at $286.2 \mathrm{eV}$ is derived from $\mathrm{C}-(\mathrm{O}, \mathrm{N})$ that is associated with alcohol, ester, amine, or amide; (iii) the peak at $287.8 \mathrm{eV}$ is assigned to $\mathrm{C}=\mathrm{O}$ or $\mathrm{O}-\mathrm{C}-\mathrm{O}$, which is included in carboxylate, carbonyl, amide, or hemiacetal; (iv) the peak at $289.0 \mathrm{eV}$ arises from $\mathrm{O}=\mathrm{C}-\mathrm{OH}$ and $\mathrm{O}=\mathrm{C}-\mathrm{OR}$, commonly found in carbonyl or ester groups. The $\mathrm{O}$ 1s peak (Figure 2B) was decomposed into two peaks: the peak at $531.3 \mathrm{eV}$ is mainly a contribution from $\mathrm{O}=\mathrm{C}$, as in carboxylate, carbonyl, ester, or amide, whereas the peak at $532.7 \mathrm{eV}$ is assigned to $\mathrm{O}-(\mathrm{C}, \mathrm{H})$, including hydroxide, acetal, and hemiacetal. Identification of acetal, hemiacetal, and 
hydroxide indicates the presence of carbohydrates, while carboxylate and carboxyl groups most likely represent the presence of proteins and acidic carbohydrates [37].

Table 2. Band assignment in the FTIR spectrum obtained from the pristine EPS based on the previous studies $[30,35,36]$.

\begin{tabular}{|c|c|c|}
\hline $\begin{array}{l}\text { Measurement } \\
\text { Data k }\left(\mathrm{cm}^{-1}\right)\end{array}$ & $\begin{array}{c}\text { Literature Data } \\
\mathbf{k}\left(\mathrm{cm}^{-1}\right)\end{array}$ & Band Assignment ${ }^{1}$ \\
\hline 1600 & $1660^{2}$ & $v \mathrm{C}=\mathrm{O}$ of amides associated with proteins (amide $\mathrm{I}$ ) \\
\hline \multirow[t]{2}{*}{15,141} & $1544^{2}$ & $\delta \mathrm{N}-\mathrm{H}$ and $\nu \mathrm{C}-\mathrm{N}$ in $-\mathrm{CO}-\mathrm{NH}-$ of proteins (amide II) \\
\hline & $1449^{2}$ & $\delta_{\mathrm{S}} \mathrm{CH}_{2}$, and $\delta \mathrm{C}-\mathrm{OH}$ \\
\hline 1374 & $1403^{2}$ & $v_{\mathrm{s}} \mathrm{C}-\mathrm{O}$ of $\mathrm{COO}^{-}$groups \\
\hline 1217 & $1242^{2}$ & $\begin{array}{l}v_{\mathrm{as}} \mathrm{P}=\mathrm{O} \text { of phosphodiester backbone of nucleic acid; may also be } \\
\text { due to phosphorylated proteins }\end{array}$ \\
\hline 1110 & $1127^{2}$ & O-H deformation, $v \mathrm{C}-\mathrm{O}$, ringvibrations of polysaccharides \\
\hline \multirow[t]{2}{*}{1044} & $1075^{3}$ & $v \mathrm{P}=\mathrm{O}$ of $\mathrm{H}_{2} \mathrm{PO}_{4}^{-}$ \\
\hline & $1078^{2}$ & $\begin{array}{l}v_{\mathrm{s}} \mathrm{P}=\mathrm{O} \text { of phosphodiester backbone of nucleic acid, } \\
\text { phosphomonoester, phosphorylated proteins, and } \mathrm{C}-\mathrm{OH} \text { stretch }\end{array}$ \\
\hline 923 & $920^{2}$ & Asymmetric ester O-P-O stretching modes from nucleic acids \\
\hline
\end{tabular}

${ }^{1}$ Superscript numbers stands for the references reporting the peak assignments. $v$ : stretching vibration. $v_{\mathrm{as}}$ : asymmetric stretching vibration. $\boldsymbol{v}_{\mathrm{s}}$ : symmetric stretching vibration. $\delta$ : scissoring vibration. ${ }^{2}[30,35],{ }^{3}[36]$.
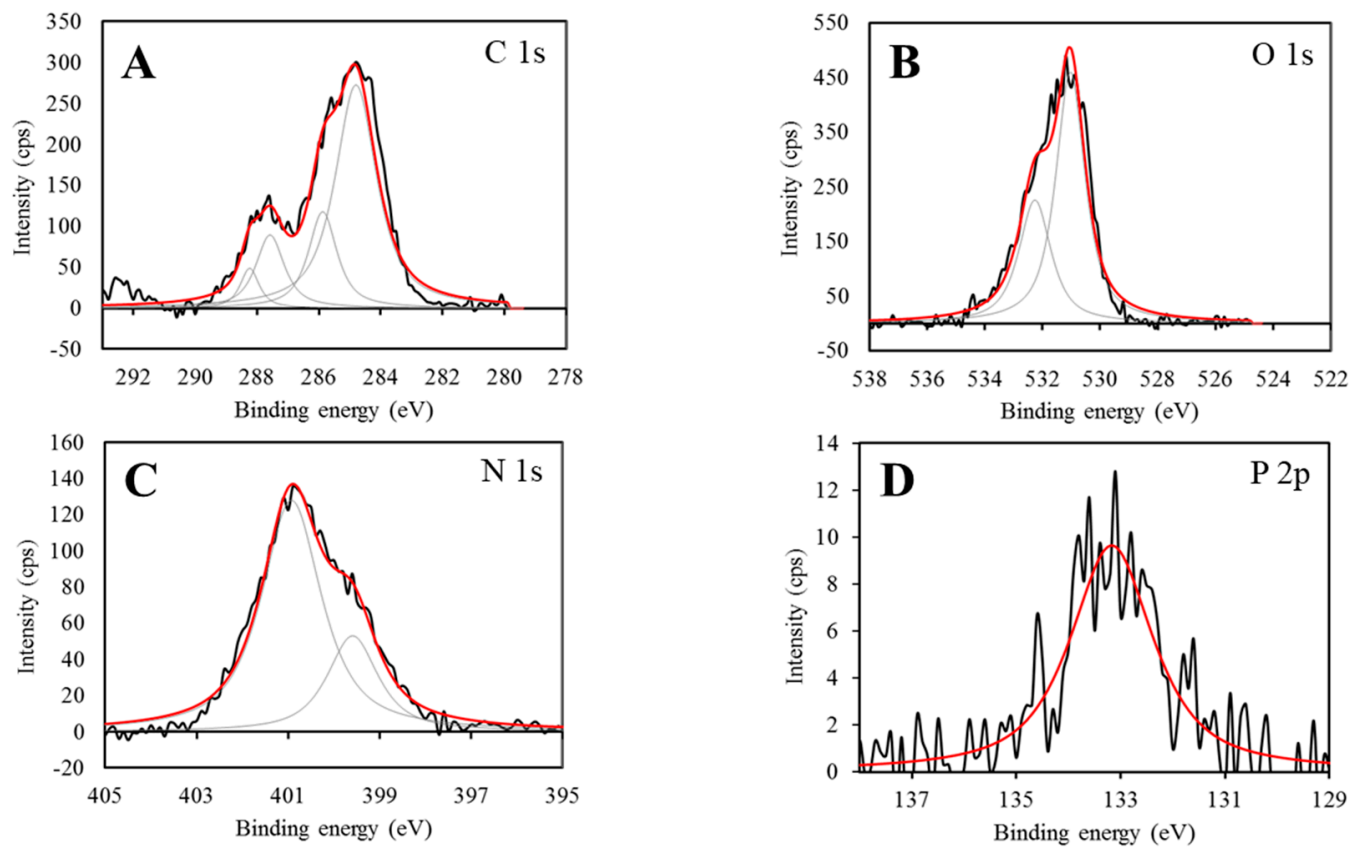

Figure 2. XPS spectra of narrow scans over C 1s (A), O 1s (B), N 1s (C), and P 2p (D) peak regions in the pristine EPS prepared at $\mathrm{pH} 6$.

The $\mathrm{N}$ 1s peak was also resolved into two component peaks (Figure 2C). The peak at $399.6 \mathrm{eV}$ can be assigned to nonprotonated nitrogen, $\mathrm{N}_{\text {nonpr }}$, such as in amines and amides, and the other peak at $401.3 \mathrm{eV}$ is mainly ascribed to protonated amines, $\mathrm{N}_{\mathrm{pr}}$ [37]. Since the EPS specimen for the present XPS analysis was prepared after adjusting the $\mathrm{pH}$ of the EPS solution to 6.0, the amount of nonprotonated amine groups in the EPS is minimal. Thus, the peak at $399.6 \mathrm{eV}$ is mainly derived from amides. 
It was difficult to resolve the P $2 \mathrm{p}$ peak due to low intensity (Figure 2D). However, two peaks typically appear at $133.2 \mathrm{eV}$ and $134.2 \mathrm{eV}$, which are derived from orthophosphate and phosphoryl group such as adenosine monophosphate, respectively. The peak assigned to phosphoryl group was not observed in this analysis because most of the phosphorus compounds in the EPS is orthophosphate (Table 1). The concentration of phosphoryl group in the EPS was too low to further analyze the peak in detail. Consequently, the results of XPS analyses suggest that the EPS released from S. cerevisiae is composed of lipids, proteins, saccharides, amines, and orthophosphate, which is consistent with the results of FTIR. On the other hand, the functional groups of EPS determined by both methods are not inconsistent with typical functional groups of the cell surfaces described in previous reports [38,39].

\subsection{Adsorption of EPS on CeNPs}

Adsorption measurements of DOC and phosphate on CeNPs at $\mathrm{pH} 6.0$ reached apparent equilibrium within only ten minutes both in the solutions with $10 \mathrm{mg} \mathrm{L}^{-1}$ (Figure $3 \mathrm{~A}$ ) and $100 \mathrm{mg} \mathrm{L}^{-1}$ (Figure 3B). The amount of adsorbed species per unit surface area on $10 \mathrm{mg} \mathrm{L}^{-1}$ of CeNPs was about an order of magnitude greater than that on $100 \mathrm{mg} \mathrm{L}^{-1}$ of CeNPs. This is because the number of availabel adsorption sites decreased for CeNPs at $100 \mathrm{mg} \mathrm{L}^{-1}$ concentration due to aggregation at this high particle concentration.
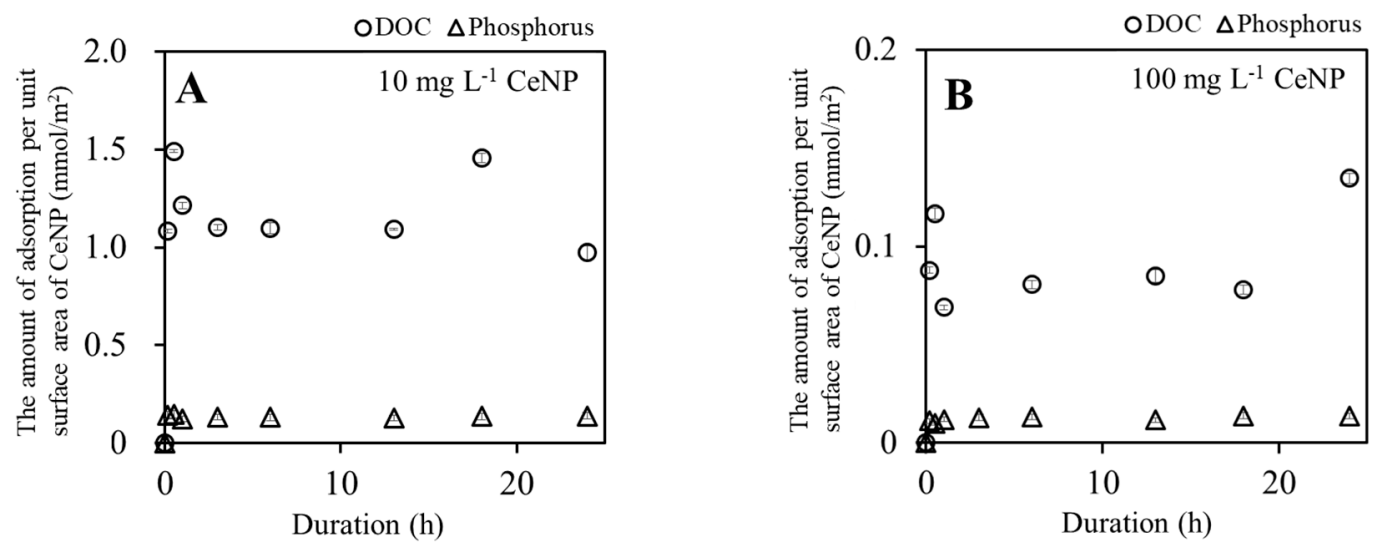

Figure 3. Time-course of the amount of DOC (circle) and phosphorus compounds (cross) adsorbed onto CeNP surfaces from EPS solutions at $\mathrm{pH}$ of 6.0. The CeNP concentrations were set to $10 \mathrm{mg} \mathrm{L}^{-1}$ (A); and $100 \mathrm{mg} \mathrm{L}^{-1}$ (B); DOC: dissolved organic carbon.

Figure 4 shows the amount of DOC (Figure 4A) and phosphorus compounds (Figure 4B) adsorbed onto CeNPs as a function of $\mathrm{pH}$ after $1 \mathrm{~h}$ of the adsorption experiment. The amount of adsorbed DOC exhibited maximum content at $\mathrm{pH} 8$ at the level of $\sim 4 \mathrm{mmol} / \mathrm{m}^{2}$. There was no $\mathrm{pH}$ dependence for the adsorption of inorganic phosphate; however, adsorption of phosphorus species derived from the EPS revealed similar $\mathrm{pH}$ dependency to that of DOC (Figure 4), despite that the majority of phosphorus compounds adsorbed onto the CeNP surfaces was identified to be orthophosphate (Table 3). Gerke found a similar phenomenon, in which phosphorous exhibited higher affinity to Fe complex with organic matter than to Fe in Fe-oxide [40]. Similarly, adsorption of DOC facilitated the phosphate adsorption onto the CeNP surfaces in the present experiment as well. 

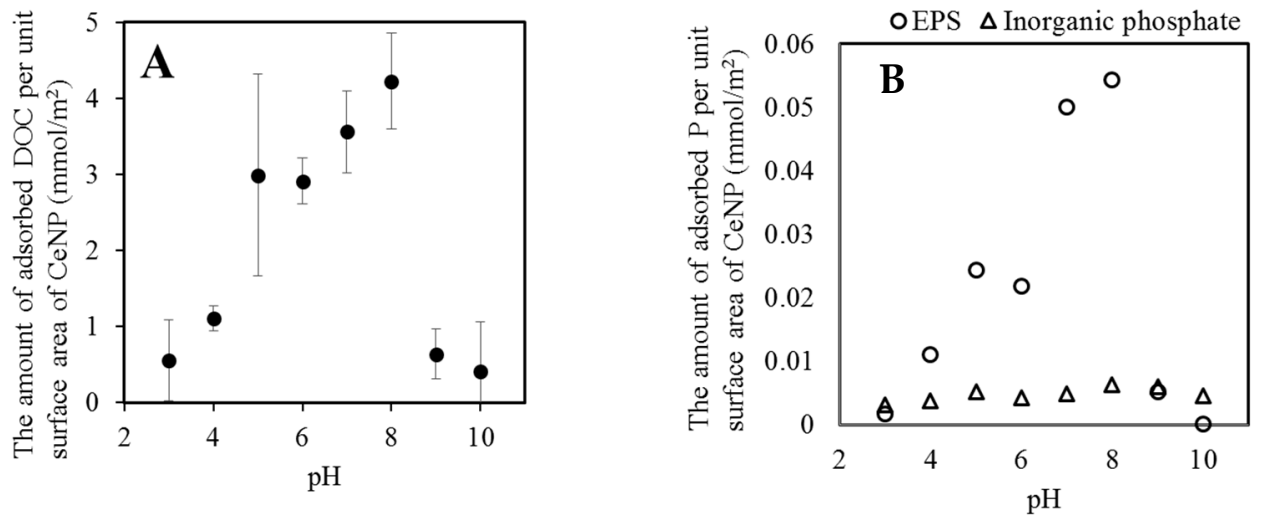

Figure 4. (A) Adsorption isotherm of DOC derived from EPS onto CeNP surfaces $\left(=10 \mathrm{mg} \mathrm{L}^{-1}\right)$ as a function of $\mathrm{pH}$ after $1 \mathrm{~h}$ of adsorption; (B) Adsorption isotherm of inorganic phosphate onto CeNP surfaces $\left(=10 \mathrm{mg} \mathrm{L}^{-1}\right)$ as a function of $\mathrm{pH}$ determined by ion chromatography (IC). The plots represent data of single measurement without standard deviation. The open circle represents the amount of adsorbed orthophosphate contained in EPS. The open triangle stands for the amount of the adsorbed inorganic phosphate.

Table 3. Summary of phosphorus compounds analyzed by an inductively coupled plasma mass spectrometry system (ICP-MS) and ion chromatography (IC). Phosphorus concentration before or after $1 \mathrm{~h}$ or adsorption experiment at $\mathrm{pH}$ of 6 is tabulated. The adsorption experiments of phosphorus compounds onto $100 \mathrm{mg} \mathrm{L}^{-1} \mathrm{CeNPs}$ were repeated four times to gain better statistics. The results from ICP-MS analysis represent total phosphorus concentration in EPS solution, while IC measures only the orthophosphate concentration. Data from both analytical methods display almost same values within the standard deviation. The amount of adsorption was calculated based on the difference between before and after adsorption experiment followed by normalization to the unit mass of CeNPs.

\begin{tabular}{|c|c|c|c|c|}
\hline & \multicolumn{2}{|c|}{ Concentration $\left(\mu \mathrm{mol} \mathrm{L}{ }^{-1}\right)$} & \multicolumn{2}{|c|}{ The Amount of Adsorption $\left(\mu \mathrm{mol} \mathrm{g}^{-1}\right)$} \\
\hline & ICP-MS & IC & ICP-MS & IC \\
\hline \multicolumn{5}{|l|}{ Before adsorption } \\
\hline EPSsolution & 179.39 & 140.81 & & \\
\hline \multicolumn{5}{|c|}{ After adsorption for $24 \mathrm{~h}$} \\
\hline 100 ppm CeNPs_1 & 155.28 & 116.15 & 241.2 & 246.6 \\
\hline 100 ppm CeNPs_2 & 151.46 & 113.41 & 279.4 & 273.9 \\
\hline 100 ppm CeNPs_3 & 152.10 & 113.13 & 272.9 & 276.8 \\
\hline 100 ppm CeNPs_4 & 149.51 & 107.84 & 298.8 & 329.6 \\
\hline Average & 152.09 & 112.63 & 273.1 & 281.7 \\
\hline Standard deviation & 2.07 & 3.01 & 20.7 & 30.1 \\
\hline
\end{tabular}

Figure 5 shows the results of the FTIR spectra of pristine CeNPs (i) and CeNPs adsorbing EPS (ii); and the difference between these two spectra (red line (iii)); which corresponds to the spectrum of only the adsorbed EPS components. The band assignments are summarized in Table 2. The FTIR spectrum explicitly revealed the significant difference in the relative intensity of the band between the adsorbed EPS (red line (iii)) and that of unreacted EPS (blue line (iv)); suggesting the preferential adsorption of particular EPS components onto the CeNPs; phosphoryl group and saccharides were preferentially adsorbed, while the relative intensity of the bands assigned to amide I, amide II and carboxyl group were suppressed after adsorption. In particular, the relative intensity of the amide II band was suppressed more than that of the amide I band. Because the amide I absorbance band is derived from the vibration of $\mathrm{C}=\mathrm{O}$ in the amide I and carboxylate, the relative decrease of amide I band indicates that protein adsorption was not a dominant process. These results are consistent with a 
previous study by Omoike and others reporting that polysaccharide and phosphate groups selectively adsorb onto amorphous $\mathrm{Al}(\mathrm{OH})_{3}$ surfaces [35], whereas less protein was adsorbed. It is already known that the adsorption of phosphate groups is configured by inner-sphere surface complexes between phosphoryl-containing compound such as phospholipids, and Fe-oxide minerals (goethite and hematite) [41], while sugar acids adsorb on the amorphous $\mathrm{Al}(\mathrm{OH})_{3}$ surface by weaker electrostatic interactions [32]. One can expect that the adsorption onto CeNP surfaces may be controlled by inner-sphere coordination and weaker electrostatic interaction.

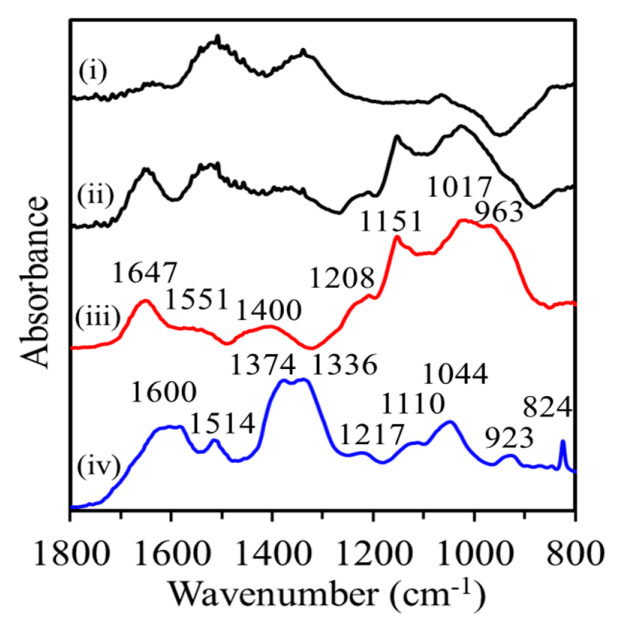

Figure 5. Results of ATR-FTIR analysis. (i) The spectrum of pristine CeNPs; (ii) The spectrum of CeNPs reacted with EPS for $1 \mathrm{~h}$ at $\mathrm{pH}$ 6.0; (iii) The difference between pristine CeNPs and CeNPs with the adsorbed EPS (red), which represents the spectrum derived from the only EPS components adsorbed onto the CeNPs; (iv) The spectrum of the unreacted EPS (blue) for comparison with (iii).

Figure 6 shows the FTIR spectra of orthophosphate in aqueous solution and orthophosphate adsorbed onto CeNPs. In aqueous solution, orthophosphate can dissociate to four species depending on the solution $\mathrm{pH}$ through the following reactions:

$$
\begin{gathered}
\mathrm{H}_{3} \mathrm{PO}_{4} \rightleftarrows \mathrm{H}_{2} \mathrm{PO}_{4}^{-}+\mathrm{H}^{+} \\
\mathrm{H}_{2} \mathrm{PO}_{4}^{-} \rightleftarrows \mathrm{HPO}_{4}^{2-}+\mathrm{H}^{+} \\
\mathrm{HPO}_{4}^{2-} \rightleftarrows \mathrm{PO}_{4}^{3-}+\mathrm{H}^{+}
\end{gathered}
$$

The dissociation constants of the above reactions are $K_{\mathrm{a} 1}=10^{-2.2}, K_{\mathrm{a} 2}=10^{-7.2}$, and $K_{\mathrm{a} 3}=10^{-12.3}$, respectively [42]. A diagram plotting the speciation of orthophosphate reveals that $\mathrm{H}_{2} \mathrm{PO}_{4}{ }^{-}$is the predominant species at solution $\mathrm{pH} 6$ (Figure S1). For the FTIR spectrum of orthophosphate in aqueous solution, the bands at 1157 and $1078 \mathrm{~cm}^{-1}$ can be assigned to the $\mathrm{P}=\mathrm{O}$ stretching mode of the $\mathrm{H}_{2} \mathrm{PO}_{4}{ }^{-}$ion, and the one at $941 \mathrm{~cm}^{-1}$ to the $\mathrm{P}-\mathrm{O}$ stretching mode of the $\mathrm{H}_{2} \mathrm{PO}_{4}{ }^{-}$ion. The band at $993 \mathrm{~cm}^{-1}$ can be assigned to the $\mathrm{P}=\mathrm{O}$ stretching mode of the $\mathrm{HPO}_{4}{ }^{2-}$ ion [36]. The FTIR spectrum of orthophosphate adsorbed onto CeNPs revealed the $\mathrm{P}=\mathrm{O}$ stretching band of the adsorbed orthophosphate species at $1070-1250 \mathrm{~cm}^{-1}$ and P-OX stretching mode of adsorbed orthophosphate $\left(\mathrm{X}=\mathrm{H}\right.$ or $\mathrm{Ce}$ ) at $845-1070 \mathrm{~cm}^{-1}$. Broadness of the bands is attributed to two factors: one is the change in the P-OX vibration frequency. The electron density of the P-OCe bond is greater than that of the $\mathrm{P}-\mathrm{OH}$ bond because of the smaller electronegativity of Ce than that of $\mathrm{H}$. Thus, the frequency of the $\mathrm{P}-\mathrm{OCe}$ vibration became greater than that of the $\mathrm{P}-\mathrm{OH}$ mode. The broadness represents that both $\mathrm{P}-\mathrm{OH}$ and P-OCe vibration are present at the CeNPs surface. The other factor is various adsorption forms such as monodentate or bidentate complexes. The frequency values of the $\mathrm{P}=\mathrm{O}$ and $\mathrm{P}-\mathrm{OX}$ vibration are altered by the adsorption form. Barja and others reported that the adsorption form is constrained by 
the adsorption density, where bridging bidentate complexes can transform to protonated monodentate complexes with increasing the adsorption density [43]. Similarly, the broadening of the bands should be partly ascribed to the multiple adsorption forms at the CeNPs surface in the present experiments. Thus, orthophosphate adsorbs onto CeNPs as an inner-sphere surface complex under both conditions with and without organic matter in the present experiment.

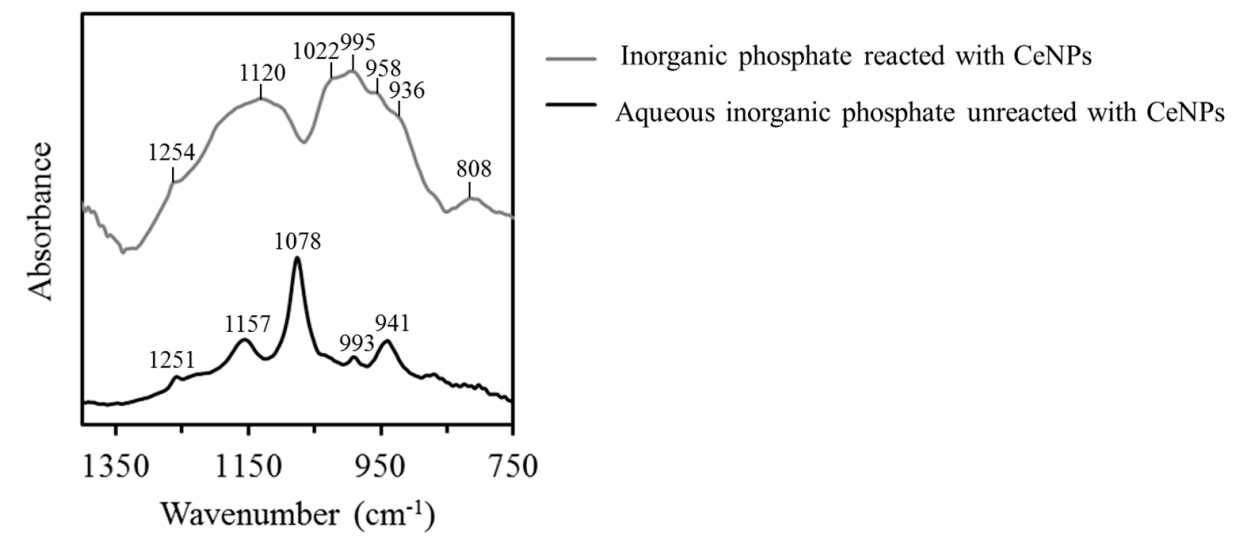

Figure 6. ATR-FTIR spectra of inorganic orthophosphate in aqueous solution and inorganic orthophosphate adsorbed onto CeNPs at $\mathrm{pH} 6.0$.

Figure 7A-D show the XPS spectra of CeNPs reacted with EPS for $1 \mathrm{~h}$. Deconvolution was performed in a similar manner to the procedure done for Figure 2. The O 1s peak at $529.0 \mathrm{eV}$ was first assigned to oxygen in $\mathrm{CeO}_{2}$. Compared to the spectrum of pristine EPS (Figure 2), the P/C molar ratio of the EPS adsorbed onto CeNPs, which was calculated based on the integrated intensity of the $\mathrm{P}$ and $\mathrm{C}$ peaks, increased from 0.026 to 0.137 (Table 4), indicating that phosphorus compounds preferentially adsorbed onto CeNP surfaces. This is consistent with the FTIR results, revealing the preferential adsorption of phosphate. The peak position of P 2p did not shift after EPS adsorption (Figures 2D and 7D), because orthophosphate is dominantly present in both cases. Table 5 summarizes the fraction of the functional groups among each element based on the integrated intensity of each corresponding peak after peak separation compared with the total intensity of peaks for each element. Notably, the fraction of $\mathrm{C}-(\mathrm{C}, \mathrm{H})$ species among total $\mathrm{C}$ species increased compared with that of the pristine EPS, indicating that organic matter containing carbon chains such as lipids, amino acid side chains, or ring chains of saccharides preferentially adsorbed onto CeNP surfaces compared with proteins and carboxylates. As for the $\mathrm{N} 1 \mathrm{~s}$ peak in the pristine EPS before the adsorption experiments, the fraction of amides (non-protonated) that are generally characterized as adenosine, nucleic acid, and amino acid is less than that of the protonated amine group (Figure 2C, Table 5). In contrast, the $\mathrm{N}$ compounds adsorbed onto CeNPs were protonated amine groups, indicating the presence of only proteins among the $\mathrm{N}$ compounds. As a consequence, XPS analysis revealed that the lipids, saccharides, and phosphates preferentially adsorbed onto CeNP surfaces, while only a small amount of proteins adsorbed. These results are consistent with that of FTIR analysis.

Table 4. Summary of the XPS analysis of major constituents in pristine EPS and EPS adsorbing onto CeNPs. The molar ratio was semi-quantitatively calculated by integrating the peak of each constituent and normalized by that of total $\mathrm{C}$.

\begin{tabular}{cccc}
\hline & \multicolumn{3}{c}{ Molar Ratio of the EPS Constituent to the Total Carbon } \\
\hline & $\mathrm{O} / \mathrm{C}$ & $\mathrm{N} / \mathrm{C}$ & $\mathrm{P} / \mathrm{C}$ \\
Pristine EPS & 1.229 & 0.386 & 0.026 \\
EPS adsorbed onto CeNPs & 2.679 & 0.235 & 0.137 \\
\hline
\end{tabular}



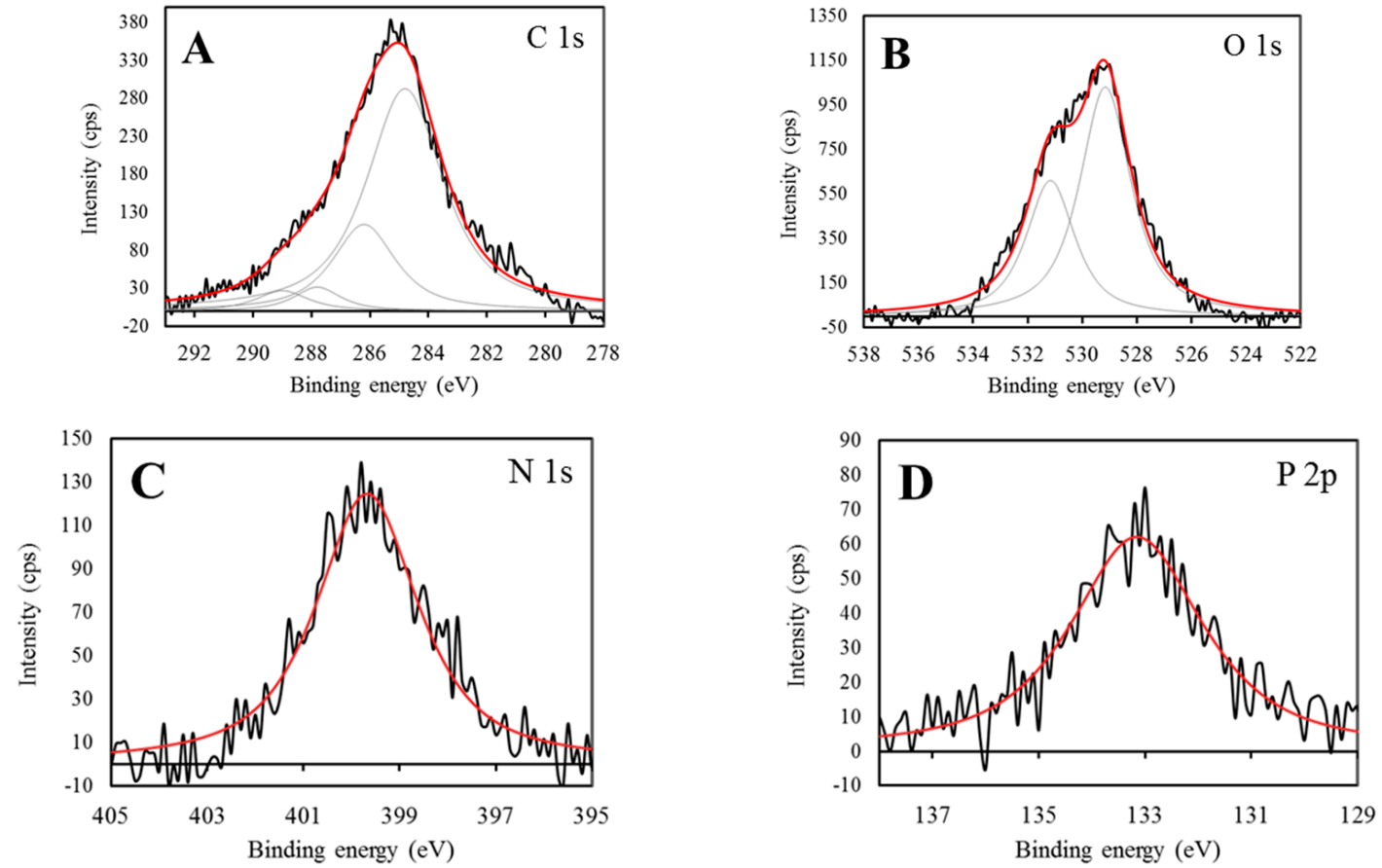

Figure 7. XPS spectra of narrow scans of C 1s (A), O 1s (B), N 1s (C), and P 2p (D) peaks of CeNPs after reaction with EPS for $1 \mathrm{~h}$.

Table 5. Summary of XPS analysis of the speciation of C, O, N, and P in pristine EPS and EPS adsorbed onto CeNPs reacted with EPS. After deconvolution, the intensity of each peak was integrated and normalized to the total integration of each element. * N.D. represents "not detected".

\begin{tabular}{|c|c|c|c|c|c|c|c|}
\hline & \multicolumn{7}{|c|}{ Fraction of Chemical Species among Each Element } \\
\hline & \multicolumn{4}{|c|}{ Carbon } & \multicolumn{3}{|c|}{ Oxygen } \\
\hline & $\begin{array}{l}284.8 \mathrm{eV} \\
\mathrm{C}-(\mathrm{C}, \mathrm{H})\end{array}$ & $\begin{array}{l}286.2 \mathrm{eV} \\
\mathrm{C}-(\mathrm{O}, \mathrm{N})\end{array}$ & $\begin{array}{c}287.8 \mathrm{eV} \\
\mathrm{C}=\mathrm{OO}-\mathrm{C}-\mathrm{O}\end{array}$ & $\begin{array}{c}289.0 \mathrm{eV} \mathrm{O}=\mathrm{C}- \\
\mathrm{OHO}=\mathrm{C}-\mathrm{OR}\end{array}$ & $\begin{array}{c}529.0 \mathrm{eV} \\
\mathrm{CeO}_{2}\end{array}$ & $\begin{array}{l}531.3 \mathrm{eV} \\
\mathrm{O}=\mathrm{C} \mathrm{O}=\mathrm{P}\end{array}$ & $\begin{array}{l}532.7 \text { eV HO- } \\
\text { CC-O-C }\end{array}$ \\
\hline Pristine EPS & 0.625 & 0.185 & 0.140 & 0.051 & - & 0.650 & 0.350 \\
\hline \multirow[t]{4}{*}{$\begin{array}{c}\text { EPS adsorbed } \\
\text { onto CeNPs }\end{array}$} & 0.780 & 0.186 & 0.026 & 0.029 & 0.639 & 0.361 & 0.000 \\
\hline & \multicolumn{7}{|c|}{ Fraction of Chemical Species among Each Element } \\
\hline & \multicolumn{4}{|c|}{ Nitrogen } & \multicolumn{3}{|c|}{ Phosphorus } \\
\hline & \multicolumn{2}{|c|}{$399.6 \mathrm{eV} \mathrm{N}_{\text {nonpr }}$} & \multicolumn{2}{|c|}{$401.3 \mathrm{eV} \mathrm{N} \mathrm{pr}_{\mathrm{pr}}$} & \multicolumn{2}{|c|}{$133.5 \mathrm{eV}$ phosphate } & $\begin{array}{c}134.2 \mathrm{eV} \\
\text { Phosphoryl group }\end{array}$ \\
\hline Pristine EPS & \multicolumn{2}{|c|}{0.259} & \multicolumn{2}{|c|}{0.741} & \multicolumn{2}{|c|}{1.000} & *N.D. \\
\hline $\begin{array}{l}\text { EPS adsorbed } \\
\text { onto CeNPs }\end{array}$ & \multicolumn{2}{|c|}{1.000} & \multicolumn{2}{|c|}{ N.D. } & \multicolumn{2}{|c|}{1.000} & *N.D. \\
\hline
\end{tabular}

\subsection{Effects of EPS on Zeta Potential of the CeNPs}

The $\zeta$ potential of 10 or $100 \mathrm{mg} \mathrm{L}^{-1} \mathrm{CeNPs}$ in $1 \mathrm{mM} \mathrm{NaCl}$ solution is plotted as a function of solution $\mathrm{pH}$ in Figure 8. The isoelectric point (iep) of the pristine CeNP surface was estimated to be 7.5 (Figure 8A), which is in good agreement with the value previously reported; 6.6 and $8.0[9,44]$. In the presence of phosphate, the $\zeta$ potential decreased dramatically, and the iep decreased to $\sim 2.0$. Regardless of the CeNP concentration, the reduction of $\zeta$ potential remained unchanged. At $\mathrm{pH}>1$, $\mathrm{H}_{2} \mathrm{PO}_{4}{ }^{-}$and/or $\mathrm{HPO}_{4}{ }^{2-}$, can be present in the solution and the $\zeta$ potential decreased due to the adsorption of anionic species on CeNP surfaces (Figure 8B). A similar mechanism was recognized in case of the phosphate adsorption onto goethite [36]. In contrast, the adsorption of EPS neutralized the 
$\zeta$ potential regardless of the CeNPs concentration (Figure 8C). Slight difference in the $\mathrm{pH}$ dependence of $\zeta$ potential between the two different CeNP concentrations may be ascribed to the different coverage of adsorbed EPS compounds over the CeNP surfaces. In the experiment of EPS adsorption, phosphate also adsorbed onto CeNP surfaces as described in the previous section, and the amount of adsorbed phosphate is greater than that in the adsorption experiment of inorganic $\mathrm{P}$ (Figure 3). Despite the fact that a greater amount of $\mathrm{P}$ is adsorbed onto the CeNP surfaces, the $\zeta$ potential appeared to be neutralized and unaffected by the phosphate adsorption. It is known that low molecular weight organic matter such as citric acids can modify the surface charge by adsorption, which typically lower the $\zeta$ potential. Thus, the neutralizing effect of EPS on the $\zeta$ potentials cannot be fully explained by the adsorption of organic matter with low molecular weight [12,45]. In general, the $\zeta$ potential reflects the potential difference between the shear plane and the bulk phase, and the shear plane potential is affected by charge of the outermost surface. In case of the EPS adsorption, saccharides and proteins are likely present at the outermost surface because the molecular size is much larger than the molecular size of orthophosphate. Thus, the effects of phosphate adsorption on the $\zeta$ potential was suppressed by adsorption of these large molecules in the EPS solution.
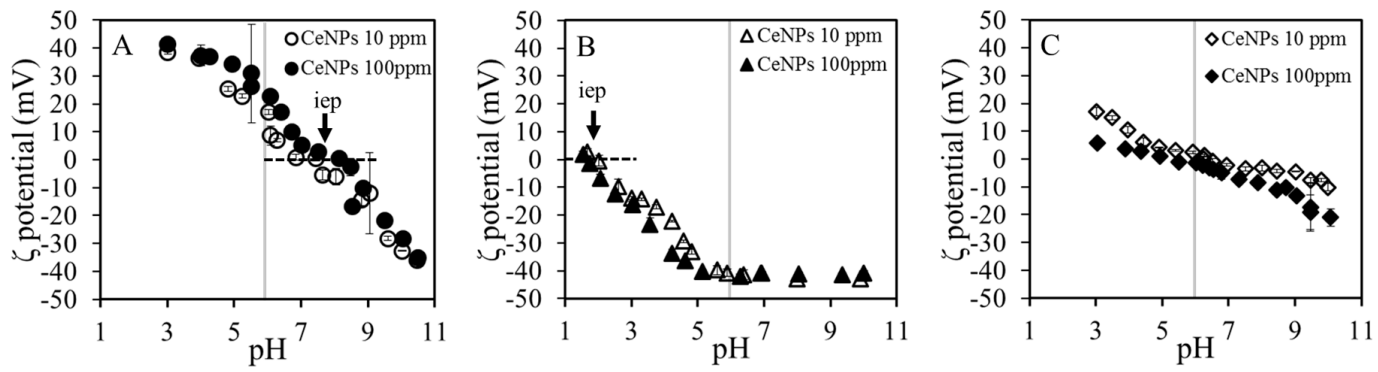

Figure 8. The $\zeta$ potential curves of CeNPs under three different conditions: (A) control solution; (B) inorganic orthophosphate solution; and (C) EPS solution. Data for two CeNP concentrations are shown: $10 \mathrm{mg} \mathrm{L}^{-1}$ (open) and $100 \mathrm{mg} \mathrm{L}^{-1}$ (closed).

\subsection{Effects of EPS on Aggregation and Sedimentation}

In the present experiments, the optical absorbance was measured using UV-Vis to analyze the turbidity of solution in three different conditions: control solution, inorganic orthophosphate solution, and EPS solution with $100 \mathrm{mg} \mathrm{L}^{-1}$ CeNP concentration. Then, the absorbance was converted to the number of particle based on theoretical considerations, which are described in detail in the Appendix A. The aggregation rate constant, $K_{\mathrm{p}}{ }^{\prime}$, was calculated based on Equation (2) as described in the materials and methods section, and the results were summarized in Table 6.

The $K_{\mathrm{p}}{ }^{\prime}$ plot as a function of ionic strength revealed a drastic increase at the different ionic strengths in the three solutions: $0.01 \mathrm{~mol} \mathrm{~L}^{-1}$ for control, $0.14 \mathrm{~mol} \mathrm{~L}^{-1}$ for inorganic phosphate, and $0.25 \mathrm{~mol} \mathrm{~L}^{-1}$ for EPS solution, which corresponds to the critical aggregation concentration, CAC. Obviously, the CACs in the inorganic phosphate and EPS solutions are greater than that in the control solution at $\mathrm{pH}$ of 6 , indicating that the adsorption of phosphate and saccharides increased the dispersibility. The enhanced dispersibility was also confirmed by the DLS analysis (Figure S2). It is noted that the CAC in the EPS solution is slightly higher than that in the inorganic phosphate solution, which may be attributed to the presence of organic molecules such as saccharides and proteins in the EPS solution. In the inorganic phosphate solution, the surface charge is strongly negative $(-40 \mathrm{mV})$ compared with that in the control solution $(+23 \mathrm{mV})$ at $\mathrm{pH} 6$ (Figure 8). It is known that the electrostatic repulsive force is effective between the particles with negative charge, because the energetic barrier appears over $\pm 20 \mathrm{mV}$ according to the DLVO theory (Figure S3). In case of the inorganic phosphate solution, the enhanced dispersibility was simply attributed to electrostatic repulsion. The aggregation rate constant dramatically increased above the CAC, because the thickness of the diffuse double layer collapses with increasing ionic strength (Equation (S5) in Supplementary Materials). On the other 
hand, in the EPS solution, the dispersibility of CeNPs was also enhanced despite the $\zeta$ potential being $\sim 0 \mathrm{mV}$ at $\mathrm{pH} 6$, indicating that the dispersibility was not enhanced only by electrostatic interaction and there is additional mechanism constraining the $\zeta$ potential in EPS. In particular, the adsorbed organic matter of EPS, predominantly saccharides and proteins, might play a role on enhancing the dispersibility in the EPS solution. Indeed, Safinajafabadi and others also reported that the colloidal stability was enhanced by the adsorption of saccharides including glucose, maltose, and dextrin [46]. Protein (bovine serum albumin) adsorption can also enhance the dispersibility of $\mathrm{SiO}_{2}$ nanoparticles near the isoelectric point [47]. In general, the adsorption of organic matter forms a steric barrier over the particles, leading to the colloidal stabilization. The steric barrier can occur even with the molecular weight as low as $\sim 650$ and becomes more significant with increasing molecular weight [48]. Hence, it is plausible that the adsorption of saccharides enhanced the colloidal stability by forming the steric barrier over CeNPs in the EPS solution in the present experiment. Although the difference in CAC between EPS solution and inorganic phosphate solution was small as revealed in Figure 9, the increment of the aggregation rate constant near CAC in the EPS solution is slightly more moderate than that in the inorganic phosphate solution, implying that the steric stabilization is relatively resistant to the effect of ionic strength compared with the electrostatic stabilization.

Table 6. Summary of the aggregation rates calculated based on the slope of Equation (2).

\begin{tabular}{ccccccc}
\hline \multirow{2}{*}{$\begin{array}{c}\text { Ionic Strength } \\
(\mathbf{m M})\end{array}$} & \multicolumn{2}{c}{ Control Condition } & \multicolumn{2}{c}{ Phosphate Condition } & \multicolumn{2}{c}{ EPS Condition } \\
\cline { 2 - 6 } & $\boldsymbol{K}_{\mathbf{p}}{ }^{\prime}$ & $\mathbf{r}^{2}$ & $\boldsymbol{K}_{\mathbf{p}}{ }^{\prime}$ & $\mathbf{r}^{2}$ & $\boldsymbol{K}_{\mathbf{p}}{ }^{\prime}$ & $\mathbf{r}^{\mathbf{2}}$ \\
\hline 1 & $2.76 \times 10^{-5}$ & 0.933 & $2.60 \times 10^{-5}$ & 0.928 & $3.19 \times 10^{-5}$ & 0.945 \\
2.5 & $4.48 \times 10^{-5}$ & 0.927 & & & & \\
5 & $4.08 \times 10^{-5}$ & 0.874 & & & & \\
7.5 & $2.42 \times 10^{-4}$ & 0.998 & & & & \\
10 & $2.61 \times 10^{-4}$ & 0.996 & $3.67 \times 10^{-5}$ & 0.938 & $1.84 \times 10^{-5}$ & 0.873 \\
100 & $2.71 \times 10^{-4}$ & 0.999 & $4.18 \times 10^{-5}$ & 0.978 & $5.43 \times 10^{-5}$ & 0.982 \\
110 & & & $1.23 \times 10^{-4}$ & 0.968 & & \\
120 & & & $1.88 \times 10^{-4}$ & 0.990 & & \\
130 & & & $2.06 \times 10^{-4}$ & 0.990 & & \\
140 & & & $2.98 \times 10^{-4}$ & 0.994 & & \\
150 & & & $2.81 \times 10^{-4}$ & 0.999 & $1.54 \times 10^{-4}$ & 0.994 \\
200 & & & $2.90 \times 10^{-4}$ & 0.999 & $2.21 \times 10^{-4}$ & 0.996 \\
250 & & & $2.63 \times 10^{-4}$ & 0.992 & $2.71 \times 10^{-4}$ & 0.998 \\
500 & & & $2.92 \times 10^{-4}$ & 0.997 & $2.70 \times 10^{-4}$ & 0.999 \\
750 & & & $2.59 \times 10^{-4}$ & 0.999 & $2.58 \times 10^{-4}$ & 0.999 \\
1000 & $2.83 \times 10^{-4}$ & 0.993 & $2.80 \times 10^{-4}$ & 0.999 & $2.57 \times 10^{-4}$ & 0.998 \\
\hline
\end{tabular}

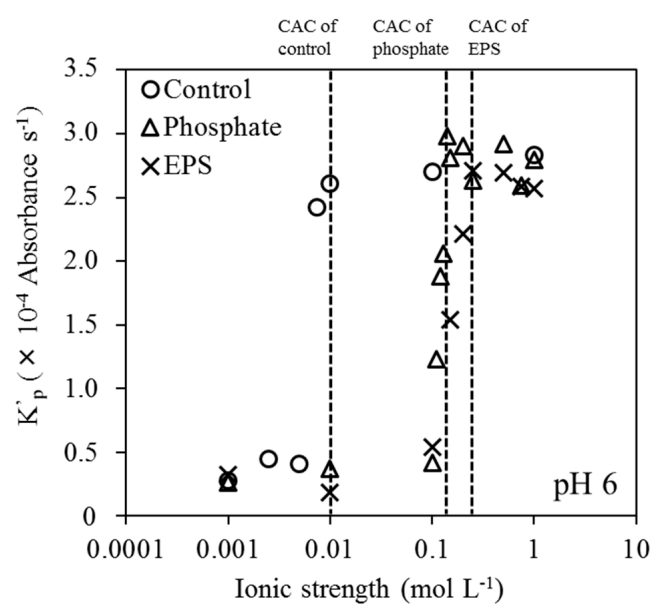

Figure 9. Aggregation rate constant of CeNPs calculated by Equation (2) for the reciprocal plot of absorbance in three different condition suspending $100 \mathrm{mg} \mathrm{L}^{-1}$ CeNPs; control condition (circle), (B) phosphate condition (triangle), and EPS condition (cross). 
Apparently natural sub-surface environment is a more complex system than the present experimental setting, because there are EPS derived from numerous kinds of microorganisms and a variety of nanoparticle phases along with many other molecular species in solution. Nevertheless, the present study at least demonstrates that EPS derived from microorganisms can adsorb to metal oxide nanoparticles with specific organic species preferentially adsorbed, modified the surface properties, and changed their stability through the steric barrier derived from organic compounds as well as the electrostatic repulsive forces of the adsorbed ionic species in EPS. In the present experiments, the EPS was released after the incubation in YPD media that contains high P content and thus, the P concentration in the EPS is most likely higher than the one released from microorganisms in subsurface environments except for the microorganisms colonized adjacent to apatite [49]. In typical shallow groundwater with the ionic strength of the order of $10^{-2} \mathrm{~mol} \mathrm{~L}^{-1}$ [14]. Hence, the adsorption of microbial EPS can potentially modify stability and transport of these colloids in groundwater.

\section{Conclusions}

Adsorption of EPS onto the surface of CeNPs and the effects on their aggregation were investigated to understand the role of microorganisms on the colloidal stability of low solubility cerium oxide nanoparticles as a surrogate of actinide oxide nanoparticles. The EPS derived from S. cerevisiae was composed of orthophosphate, organic phosphorous compounds, and various types of organic matter including polysaccharides and proteins. Among the EPS constituents, polysaccharides and orthophosphate preferentially adsorbed onto CeNPs. Aggregation of CeNPs was suppressed by the adsorption of EPS because of the electrostatic repulsive forces derived from the adsorbed orthophosphate and the steric barrier formed by the organic matter on the surface of CeNPs. The present study suggests that the specific EPS components adsorbed to metal oxide nanoparticles during the interaction between microorganisms and nanoparticles can cause colloidal stabilization depending on the $\mathrm{pH}$ conditions in the environment, which may facilitate colloid transport.

Supplementary Materials: The following are availabel online at www.mdpi.com/2076-3298/4/3/48/s1, Figure S1: Fraction of phosphate species in solution as a function of $\mathrm{pH}$, Figure S2: Time-dependent variation in the average size of CeNP aggregates at $100 \mathrm{mg} \mathrm{L}^{-1}$ CeNP concentration monitored by dynamic light scattering (DLS): $(\bigcirc)$ control solution, $(\triangle)$ inorganic orthophosphate solution, and $(\diamond)$ EPS solution, Figure S3: Net energy of interaction for particles with various surface potentials at the constant ionic strength associated with the short description of the theory on which the calculation is based.

Acknowledgments: The authors would like to thank the members of the bio-actinide group at JAEA. This work was partially supported by the Grant-in-Aid for Scientific Research (KAKENHI) from the Japan Society for the Promotion of Science (16K12585, 16H04634, No. JP26257402), and the Basic Research Fund of the Radioactive Waste Management Funding and Research Center.

Author Contributions: Satoshi Utsunomiya conceived and designed the experiments; Shota Masaki and Yuriko Nakano performed the experiments and analyzed the data; Kenta Ichiyoshi, Keisuke Kawamoto, Ayaka Takeda, and Toshihiko Ohnuki helped the discussion; Shota Masaki and Satoshi Utsunomiya wrote the paper; Michael F. Hochella, Jr. assisted discussion and revision.

Conflicts of Interest: The authors declare no conflict of interest.

\section{Appendix A}

\section{Effect of Particle Size on Back-Scattering Light Intensity}

Although the size of single $\mathrm{CeO}_{2}$ nanoparticle is $5 \mathrm{~nm}$ on average, the hydrodynamic diameter of aggregate was measured to be $\sim 400 \mathrm{~nm}$ by DLS analysis. The real size of aggregates can be estimated to be several hundred nanometers. Because the wavelength of light used in measurement is $340 \mathrm{~nm}$, which is similar to the size of aggregate, the Mie theory can be applied to simulate the effect of particle size on the back-scattering intensity in the present study. Assuming the shape of the aggregate as a sphere, the relationship of incident light intensity and scattered light intensity to the size of aggregate 
can be formulated based on the Mie theory. The scattering cross section $\sigma_{\mathrm{SCA}}$ can be calculated as follows [50]:

$$
\begin{gathered}
\sigma_{\mathrm{SCA}}=Q_{\mathrm{SCA}} \times \pi a^{2} \\
Q_{\mathrm{SCA}}=\frac{2}{x^{2}} \sum_{n=1}^{\infty}(2 n+1)\left(\left|a_{n}\right|^{2}+\left|b_{n}\right|^{2}\right) \\
a_{n}=\frac{\left[D_{n}(m x) / m+n / x\right] \psi_{n}(x)-\psi_{n-1}(x)}{\left[D_{n}(m x) / m+n / x\right] \xi_{n}(x)-\xi_{n-1}(x)} \\
b_{n}=\frac{\left[m \times D_{n}(m x)+n / x\right] \psi_{n}(x)-\psi_{n-1}(x)}{\left[m \times D_{n}(m x)+n / x\right] \xi_{n}(x)-\xi_{n-1}(x)} \\
D_{n}(x)=\frac{d \ln \psi(x)}{d x}=\frac{\psi^{\prime}(x)}{\psi(x)} D_{n}(x)=\frac{n}{x}-\frac{1}{D_{n}(x)+\frac{n}{x}}
\end{gathered}
$$

At adequate order, $D_{n}(x)=0$

$Q_{\text {SCA }}$ : Efficiency factor

$n$ : Particles of order in light path

$x$ : Size parameter $(=2 \pi a / \lambda)$

$a$ : Particle radius $(\mathrm{nm})$

$\lambda$ : Wavelength (nm)

$m$ : Reflectance ratio of particle (In case of $\mathrm{CeO}_{2}, m=2.2$ at $\lambda=550 \mathrm{~nm}$ )

Hence, $\Psi$ and $\xi$ is called Riccati-Bessel function, and they are described as follows.

$$
\begin{gathered}
\psi_{n+1}(x)=\frac{2 n+1}{x} \psi_{n}(x)-\psi_{n-1}(x) \\
\psi_{n}^{\prime}(x)=\psi_{n-1}(x)-\frac{n}{x} \psi_{n}(x) \\
\psi_{-1}(x)=\cos x, \psi_{0}(x)=\sin x \\
\xi_{n+1}(x)=\frac{2 n+1}{x} \xi_{n}(x)-\xi_{n-1}(x) \\
\xi_{n}^{\prime}(x)=\xi_{n-1}(x)-\frac{n}{x} \xi_{n}(x) \\
\xi_{-1}(x)=\exp i x, \xi_{0}(x)=-i \times \exp i x
\end{gathered}
$$

Figures A1 and A2 show the result of calculating Equation (A2) for the size parameter, $x$. It is obvious that the efficiency factor of scattering did not change significantly for $x>2$. Considering that the wavelength of light used in measurement is $340 \mathrm{~nm}$ and the hydrodynamic diameter of aggregate was $\sim 400 \mathrm{~nm}$, the size parameter can be estimated greater than 3.7 in the present study. Thus, the scattering intensity remains unaffected by the change in particle size in the present experimental conditions. 


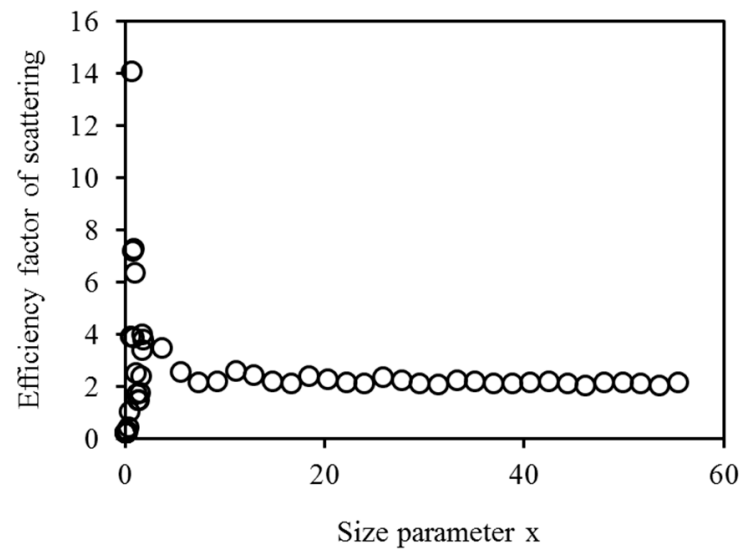

Figure A1. Efficiency factor of light scattering as a function of the size parameter calculated based on the Mie theory.

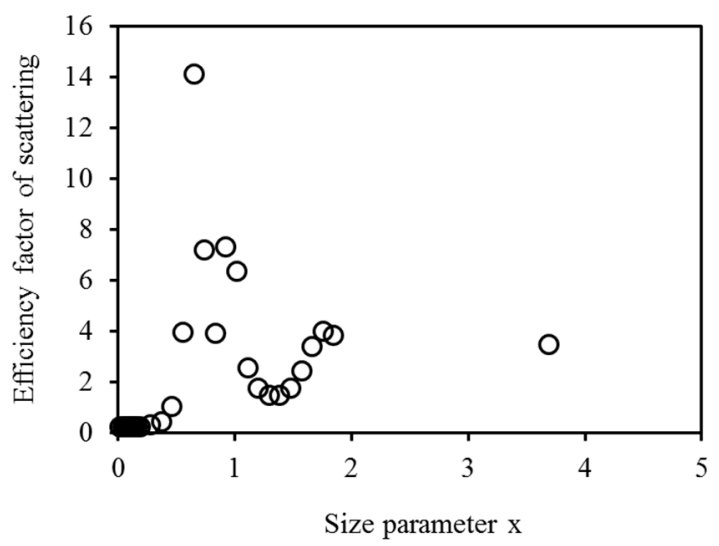

Figure A2. A diagram enlarged along the axis of size parameter $x$ focusing on the range from 0 to 5 .

\section{References}

1. Banfield, J.F.; Zhang, H. Nanoparticles and the environment. In Reviews in Mineralogy E Geochemistry; Banfield, J.F., Navrotsky, A., Eds.; The Mineralogical Socienty of America: Washington, DC, USA, 2001; Volume 3, pp. 1-58.

2. Hochella, M.F., Jr.; Lower, S.K.; Maurice, P.A.; Penn, R.L.; Sahai, N.; Sparks, D.L.; Twining, B.S. Nanominerals, mineral nanoparticles, and Earth systems. Science 2008, 319, 1631-1635. [CrossRef] [PubMed]

3. Wiesner, M.R.; Lowry, G.V.; Casman, E.; Bertsch, P.M.; Matson, C.W.; Di Giulio, R.T.; Liu, J.; Hochella, M.F., Jr. Meditations on the Ubiquity and Mutability of Nano-Sized Materials in the Environment. ACS Nano 2011, 5, 8466-8470. [CrossRef] [PubMed]

4. McCarthy, J.F.; Zachara, J.M. Subsurface transport of contaminants. Environ. Sci. Technol. 1989, 23, 496-502. [CrossRef]

5. Honeyman, B.D. Colloidal culprits in contamination. Nature 1999, 397, 23-24. [CrossRef]

6. Nagasaki, S.; Tanaka, S.; Suzuki, A. Fast Transport of Colloidal Particles through Quartz-Packed Columns. J. Nucl. Sci. Technol. 1993, 30, 1136-1144. [CrossRef]

7. Kersting, A.; Efurd, D.; Finnegan, D.; Rokop, D.; Smith, D.; Thompson, J. Migration of plutonium in ground water at the Nevada Test Site. Nature 1999, 397, 56-59. [CrossRef]

8. Novikov, A.P.; Kalmykov, S.N.; Utsunomiya, S.; Ewing, R.C.; Horreard, F.; Merkulov, A.; Clark, S.B.; Tkachev, V.V.; Myasoedov, B.F. Colloid transport of plutonium in the far-field of the Mayak Production Association, Russia. Science 2006, 314, 638-641. [CrossRef] [PubMed]

9. Buettner, K.M.; Rinciog, C.I.; Mylon, S.E. Aggregation kinetics of cerium oxide nanoparticles in monovalent and divalent electrolytes. Colloids Surf. A. 2010, 366, 74-79. [CrossRef] 
10. Hu, J.; Zevi, Y.; Kou, X.; Xiao, J.; Wang, X.; Jin, Y. Effect of dissolved organic matter on the stability of magnetite nanoparticles under different $\mathrm{pH}$ and ionic strength conditions. Sci. Total. Environ. 2010, 408, 3477-3489. [CrossRef] [PubMed]

11. Tourney, J.; Ngwenya, B.T. The effect of ionic strength on the electrophoretic mobility and protonation constants of an EPS-producing bacterial strain. J. Colloid Interface Sci. 2010, 348, 348-354. [CrossRef] [PubMed]

12. Johnson, S.B.; Brown, G.E., Jr.; Healy, T.W.; Scales, P.J. Adsorption of organic matter at mineral/water interfaces 6. Effect of inner-sphere versus outer-sphere adsorption on colloidal stability. Langmuir 2005, 21, 6356-6365. [CrossRef] [PubMed]

13. Domingos, R.F.; Tufenkji, N.; Wilkinson, K.J. Aggregation of Titanium Dioxide Nanoparticles: Role of a Fulvic Acid. Environ. Sci. Technol. 2009, 43, 1282-1286. [CrossRef] [PubMed]

14. Keller, A.A.; Wang, H.; Zhou, D.; Lenihan, H.S.; Cherr, G.; Cardinale, B.J.; Miller, R.; Ji, Z. Stability and Aggregation of Metal Oxide Nanoparticles in Natural Aqueous Matrices. Environ. Sci. Technol. 2010, 44, 1962-1967. [CrossRef] [PubMed]

15. Thio, B.J.R.; Zhou, D.; Keller, A.A. Influence of natural organic matter on the aggregation and deposition of titanium dioxide nanoparticles. J. Hazard. Mater. 2011, 189, 556-563. [CrossRef] [PubMed]

16. Beveridge, T.J.; Makin, S.A.; Kadurugamuwa, J.L.; Li, Z.S. Interactions between biofilms and the environment. FEMS Microbiol. Rev. 1997, 20, 291-303. [CrossRef] [PubMed]

17. Kumar, A.S.; Mody, K.; Jha, B. Bacterial exopolysaccharides-A perception. J. Basic Microbiol. 2007, 47, 103-117. [CrossRef] [PubMed]

18. Tourney, J.; Ngwenya, B.T. The role of bacterial extracellular polymeric substances in geomicrobiology. Chem. Geol. 2014, 386, 115-132. [CrossRef]

19. Schwegmann, H.; Feitz, A.J.; Frimmel, F.H. Influence of the zeta potential on the sorption and toxicity of iron oxide nanoparticles on S. cerevisiae and E. coli. J. Colloid Interface Sci. 2010, 347, 43-48. [CrossRef] [PubMed]

20. Ohnuki, T.; Ozaki, T.; Yoshida, T.; Sakamoto, F.; Kozai, N.; Wakai, E.; Francis, A.J.; Iefuji, H. Mechanisms of uranium mineralization by the yeast Saccharomyces cerevisiae. Geochim. Cosmochim. Acta 2005, 69, 5307-5316. [CrossRef]

21. Jiang, M.; Ohnuki, T.; Kozai, N.; Tanaka, K.; Suzuki, Y.; Sakamoto, F.; Kamiishi, E.; Utsunomiya, S. Biological nano-mineralization of Ce phosphate by Saccharomyces cerevisiae. Chem. Geol. 2010, 277, 61-69. [CrossRef]

22. Xu, J.; Murayama, M.; Roco, C.M.; Veeramani, H.; Michel, F.M.; Rimstidt, J.D.; Winkler, C.; Hochella, M.F., Jr. Highly-defective nanocrystals of $\mathrm{ZnS}$ formed via dissimilatory bacterial sulfate reduction: A comparative study with their abiogenic analogues. Geochim. Cosmochim. Acta 2016, 180, 1-14. [CrossRef]

23. Jiang, M.; Ohnuki, T.; Tanaka, K.; Kozai, N.; Kamiishi, E.; Utsunomiya, S. Post-adsorption process of Yb phosphate nano-particle formation by Saccharomyces cerevisiae. Geochim. Cosmochim. Acta 2012, 93, 30-46. [CrossRef]

24. Adeleye, A.S.; Conway, J.R.; Perez, T.; Rutten, P.; Keller, A.A. Influence of extracellular polymeric substances on the long-term fate, dissolution, and speciation of copper-based nanoparticles. Environ. Sci. Technol. 2014, 48, 12561-12568. [CrossRef] [PubMed]

25. Adeleye, A.S.; Keller, A.A. Interactions between algal extracellular polymeric substances and commercial $\mathrm{TiO}_{2}$ nanoparticles in aqueous media. Environ. Sci. Technol. 2016, 50, 12258-12265. [CrossRef] [PubMed]

26. Lin, D.; Story, S.D.; Walker, S.L.; Huang, Q.; Liang, W.; Cai, P. Role of $\mathrm{pH}$ and ionic strength in the aggregation of extracellular polymeric substances from Bacillus subtilis. Environ. Pollut. 2017, 228, 35-42. [CrossRef] [PubMed]

27. Kroll, A.; Behra, B.; Kaegi, R.; Sigg, L. Extrcellular polymeric substances (EPS) of freshwater biofilms stabilize and modify $\mathrm{CeO}_{2}$ and Ag nanoparticles. PLoS ONE 2014, 9, e110709. [CrossRef] [PubMed]

28. Cao, Y.; Wei, X.; Cai, P.; Huang, Q.; Rong, X.; Liang, W. Preferential adsorption of extracellular polymeric substances from bacteria on clay minerals and iron oxide. Colloid Surf. B 2011, 83, 122-127. [CrossRef] [PubMed]

29. Masaki, S.; Shiotsu, H.; Ohnuki, T.; Sakamoto, F.; Utsunomiya, S. Effects of $\mathrm{CeO}_{2}$ nanoparticles on microbial metabolism. Chem. Geol. 2015, 391, 33-41. [CrossRef]

30. Omoike, A.; Chorover, J. Adsorption to goethite of extracellular polymeric substances from Bacillus subtilis. Geochim. Cosmochim. Acta 2006, 70, 827-838. [CrossRef] 
31. Hay, M.B.; Myneni, S.C.B. Structural environments of carboxyl groups in natural organic molecules from terrestrial systems. Part 1: Infrared spectroscopy. Geochim. Cosmochim. Acta 2007, 71, 3518-3532. [CrossRef]

32. Mikutta, R.; Zang, U.; Chorover, J.; Haumaier, L.; Kalbitz, K. Stabilization of extracellular polymeric substances (Bacillus subtilis) by adsorption to and coprecipitation with Al forms. Geochim. Cosmochim. Acta 2011, 75, 3135-3154. [CrossRef]

33. González, A.G.; Shirokova, L.S.; Pokrovsky, O.S.; Emnova, E.E.; Martínez, R.E.; Santana-Casiano, J.M.; González-Dávila, M.; Pokrovski, G.S. Adsorption of copper on Pseudomonas auroeofaciens: Protective role of surface exopolysaccharides. J. Colloid Interface Sci. 2010, 350, 305-314. [CrossRef] [PubMed]

34. Veiga, M.C.; Jain, M.K.; Wu, W.M.; Hollingsworth, R.I.; Zeikus, J.G. Composition and Role of Extracellular Polymers in Methanogenic Granules. Appl. Environ. Microbiol. 1997, 63, 403-407. [PubMed]

35. Omoike, A.; Chorover, J.; Kwon, K.; Kubicki, J. Adhesion of bacterial exopolymers to $\alpha$-FeOOH: Inner-sphere complexation of phosphodiester groups. Langmuir 2004, 20, 11108-11114. [CrossRef] [PubMed]

36. Tejedor-Tejedor, M.; Anderson, M. Protonation of Phosphate on the Surface of Goethite as Studied by CIR-FTIR and Electrophoretic Mobility. Langmuir 1990, 6, 602-611. [CrossRef]

37. Badireddy, A.R.; Korpol, B.R.; Chellam, S.; Gassman, P.L.; Engelhard, M.H.; Lea, A.S.; Rosso, K.M. Spectroscopic Characterization of Extracellular Polymeric Substances from Escherichia coli and Serratia marcescens: Suppression Using Sub-Inhibitory Concentrations of Bismuth Thiols. Biomacromolecules 2008, 9, 3079-3089. [CrossRef] [PubMed]

38. Borrok, D.; Fein, J.B.; Kulpa, C.F. Proton and Cd adsorption onto natural bacterial consortia: Testing universal adsorption behavior. Geochim. Cosmochim. Acta 2004, 68, 3231-3238. [CrossRef]

39. Fein, J.; Martin, A.M.; Wightman, P.G. Metal adsorption onto bacterial surfaces: Development of a predictive approach. Geochim. Cosmochim. Acta 2001, 65, 4267-4273. [CrossRef]

40. Gerke, J. Phosphate adsorption by humic/Fe-oxide mixtures aged at $\mathrm{pH} 4$ and 7 and by poorly ordered Fe-oxide. Geoderma 1993, 59, 279-288. [CrossRef]

41. Cagnasso, M.; Boero, V.; Franchini, M.A.; Chorover, J. ATR-FTIR studies of phospholipid vesicle interactions with alpha-FeOOH and $\alpha-\mathrm{Fe}_{2} \mathrm{O}_{3}$ surfaces. Colloids Surf. B 2010, 76, 456-467. [CrossRef] [PubMed]

42. Stumm, W.; Morgan, J.J. Aquatic Chemistry: An. Introduction Emphasizing Chemical Equilibria in Natural Waters, 2nd ed.; John Wiley \& Sons, Inc.: New York, NY, USA, 1981.

43. Barja, B.; Tejedor-Tejedor, M.; Anderson, M. Complexation of methylphosphonic acid with the surface of goethite particles in aqueous solution. Langmuir 1999, 15, 2316-2321. [CrossRef]

44. Pelletier, D.A.; Suresh, A.K.; Holton, G.A.; McKeown, C.K.; Wang, W.; Gu, B.; Mortensen, N.P.; Allison, D.P.; Joy, D.C.; Allison, M.R.; et al. Effects of Engineered Cerium Oxide Nanoparticles on Bacterial Growth and Viability. Appl. Environ. Microbiol. 2010, 76, 7981-7989. [CrossRef] [PubMed]

45. Hanaor, D.; Michelazzi, M.; Leonelli, C.; Sorrell, C.C. The effects of carboxylic acids on the aqueous dispersion and electrophoretic deposition of $\mathrm{ZrO}_{2}$. J. Eur. Ceram. Soc. 2012, 32, 235-244. [CrossRef]

46. Safinajafabadi, A.; Sarraf-Mamoory, R.; Karimi, Z. Effect of organic dispersants on structural and mechanical properties of $\mathrm{Al}_{2} \mathrm{O}_{3} / \mathrm{ZrO}_{2}$ composites. Mater. Res. Bull. 2012, 47, 4210-4215. [CrossRef]

47. Givens, B.E.; Diklich, N.D.; Fiegel, J.; Grassian, V.H. Adsorption of bovine serum albumin on silicon dioxide nanoparticles: Impact of $\mathrm{pH}$ on nanoparticle-protein interactions. Biointerphases 2017, 12, 02D404. [CrossRef] [PubMed]

48. Stenkamp, V.; Berg, J. The role of long tails in steric stabilization and hydrodynamic layer thickness. Langmuir 1997, 13, 3827-3832. [CrossRef]

49. Taunton, A.E.; Welch, S.A.; Banfield, J.F. Microbial controls on phosphate and lanthanide distributions during granite weathering and soil formation. Chem. Geol. 2000, 169, 371-382. [CrossRef]

50. Mie, G. Beiträge zur Optik trüber Medien, speziell kolloidaler Metallösungen. Ann. Phys. 1908, 333, 377-445. [CrossRef]

(C) 2017 by the authors. Licensee MDPI, Basel, Switzerland. This article is an open access article distributed under the terms and conditions of the Creative Commons Attribution (CC BY) license (http:/ / creativecommons.org/licenses/by/4.0/). 